University of Nebraska - Lincoln

DigitalCommons@University of Nebraska - Lincoln

Papers in Veterinary and Biomedical Science

Veterinary and Biomedical Sciences,

Department of

1999

\title{
In Situ Hybridization for the Detection and Localization of Swine Chlamydia trachomatis
}

C. Chae

College of Veterinary Medicine

D.-S. Cheon

College of Veterinary Medicine

D. Kwon

College of Veterinary Medicine

O. Kim

College of Veterinary Medicine

B. Kim

College of Veterinary Medicine

See next page for additional authors

Follow this and additional works at: https://digitalcommons.unl.edu/vetscipapers

Part of the Biochemistry, Biophysics, and Structural Biology Commons, Cell and Developmental Biology Commons, Immunology and Infectious Disease Commons, Medical Sciences Commons, Veterinary Microbiology and Immunobiology Commons, and the Veterinary Pathology and Pathobiology Commons

Chae, C.; Cheon, D.-S.; Kwon, D.; Kim, O.; Kim, B.; Suh, J.; Rogers, D. G.; Everett, K. D. E.; and Anderson, A. A., "In Situ Hybridization for the Detection and Localization of Swine Chlamydia trachomatis" (1999). Papers in Veterinary and Biomedical Science. 142.

https://digitalcommons.unl.edu/vetscipapers/142

This Article is brought to you for free and open access by the Veterinary and Biomedical Sciences, Department of at DigitalCommons@University of Nebraska - Lincoln. It has been accepted for inclusion in Papers in Veterinary and Biomedical Science by an authorized administrator of DigitalCommons@University of Nebraska - Lincoln. 


\section{Authors}

C. Chae, D.-S. Cheon, D. Kwon, O. Kim, B. Kim, J. Suh, D. G. Rogers, K. D. E. Everett, and A. A. Anderson 


\title{
In Situ Hybridization for the Detection and Localization of Swine Chlamydia trachomatis
}

\author{
C. Chae, D.-S. Cheon, D. Kwon, O. Kim, B. Kim, J. Suh, D. G. Rogers, \\ K. D. E. Everett, and A. A. Andersen \\ Department of Veterinary Pathology, College of Veterinary Medicine, Seoul National University, \\ Suwon, Republic of Korea (CC, DSC, DK, OK, BK, JS); \\ Veterinary Diagnostic Center, Department of Veterinary and Biomedical Science, \\ University of Nebraska, Lincoln, NE (DGR); and \\ National Animal Disease Center, USDA, Agricultural Research Service, Ames, IA (KDEE, AAA)
}

\begin{abstract}
Gnotobiotic piglets were inoculated intralaryngeally with swine Chlamydia trachomatis strain R33 or orally with swine C. trachmatis strain R27. Archived formalin-fixed, paraffin-embedded tissues from piglets euthanatized 4-7 days postinoculation were examined by in situ hybridization for $C$. trachomatis nucleic acid using a nonradioactive digoxigenin-labeled DNA probes that targeted specific ribosomal RNA or omp1 mRNA molecules of the swine $C$. trachomatis strains. Positive hybridization signals were detected in bronchial epithelial cells, bronchiolar epithelial cells, pneumocytes, alveolar and interstitial macrophages, and jejunal and ileal enterocytes. Chlamydia-infected cells had a strong signal that was confined to the intracytoplasmic inclusions. Positive hybridization signals were not detected in tissue sections from an uninfected control piglet or in C. psittaci-infected sheep placenta. The morphology of host cells was preserved despite the relatively high temperature required in parts of the incubation procedure. The data indicate that in situ hybridization can be used to detect swine $C$. trachomatis in formalin-fixed, paraffin-embedded tissue specimens.
\end{abstract}

Key words: Chlamydia trachomatis; enteritis; in situ hybridization; pneumonia; swine.

Chlamydiae are gram-negative intracellular parasitic bacteria, and four species have been described. Strains of Chlamydia trachomatis and C. pneumoniae infect human beings, and strains of C. psittaci and C. pecorum are predominantly animal pathogens. ${ }^{27}$ Although chlamydiae have been isolated from and/or detected in cases of pneumonia, enteritis, conjunctivitis, polyarthritis, pericarditis, perinatal mortality, and reproductive disorders in swine, , $4,17,18,21,24,26,28,29,31-33$ some of these swine chlamydial strains have only recently been characterized and are believed to be $C$. trachomatis or C. trachomatis-like strains. ${ }^{7,13,34}$

Chlamydia and chlamydia-like organisms have one or two copies of a typical eubacterial ribosomal operon that contains no tRNAs. In this operon, variable sequences in the ribosomal $16 \mathrm{~S} / 23 \mathrm{~S}$ intergenic spacer and in Domain I of the 23S gene are specific for each of nine different phylogenetic groups of chlamydiae. The group containing chlamydial strains from European and American swine is closely related to human and mouse strains of C. trachomatis. ${ }^{7}$

Swine chlamydial strains R33 and R27, originally isolated from nursery pigs with pneumonia and diarrhea, respectively, are pathogens in gnotobiotic piglets. ${ }^{20,22}$ Both of these strains are currently classified as C. trachomatis or C. trachomatis-like chlamydiae. ${ }^{7}$
The objective of the present study was to develop an in situ hybridization technique using a nonradioactive digoxigenin-labeled DNA probe that targeted specific ribosomal RNA (rRNA) molecules of these swine $C$. trachomatis strains in formalin-fixed, paraffin-embedded tissue specimens.

\section{Materials and Methods}

\section{Tissue specimens}

Archived formalin-fixed, paraffin-embedded tissue specimens from gnotobiotic piglets inoculated intralaryngeally with swine C. trachomatis strain R33 and from gnotobiotic piglets inoculated orally with swine $C$. trachomatis strain R27 were used as test specimens. ${ }^{20,22}$ The piglets infected intralaryngeally with strain R33 were necropsied 7 days postinoculation, and the piglets inoculated orally with strain R27 ( $10^{9}$ colony-forming units) were necropsied 4 days postinoculation. ${ }^{20,22}$

Intestinal and lung tissue specimens from an uninfected 1-day-old colostrum-deprived piglet, lung tissue from a 5week-old conventional pig infected with Actinobacillus pleuropneumoniae, and intestinal tissues from a 1-week-old conventional pig infected with Escherichia coli served as negative tissue controls. Placenta from a ewe that had been experimentally infected with $C$. psittaci also was used as a negative tissue control. 


\section{Preparation of the $C$. trachomatis-specific probes}

Probes were prepared by polymerase chain reaction (PCR) amplification of chlamydial genomic DNA from two swine strains (R33 and R27) of C. trachomatis grown in Vero cell monolayers. ${ }^{8}$ Chlamydiae were isolated from the infected cells and medium by adding Renograffin (Solvay Animal Health, Mendota Heights, MN) to a final concentration of $29 \%$, incubating at room temperature for 10 minutes, breaking up the Vero cell DNA with a syringe using a 20-26gauge needle, and centrifuging for 20 minutes at 11,000 rpm. The chlamydial pellets were washed three or four times in phosphate-buffered saline (PBS), resuspended in 50-100 $\mu \mathrm{l}$ of buffer containing $50 \mathrm{mM}$ dithiothreitol and $30 \mathrm{mM}$ Tris/ $10 \mathrm{mM}$ ethylenediaminetetraacetic acid (EDTA) ( $\mathrm{pH} \mathrm{9.0),}$ and incubated for 1 hour at $37 \mathrm{C}$. An equal volume of $1 \%$ Nonidet P-40 and a small amount of RNase was then added. The DNA preparations were incubated at $37 \mathrm{C}$ for 1 hour and then extracted with phenol/chloroform and chloroform. ${ }^{23}$ Approximately $0.5 \mu \mathrm{g}$ of chlamydial DNA was used in each $100-\mu \mathrm{l}$ PCR. The $0.5-\mathrm{kb}$ probe defined by primer $170\left(5^{\prime}-\right.$ TCGTAACAAGGTAGCCC-3') and primer 23R (5'-TACTAAGATGTTTCAGTTC-3') encompasses the group-specific $16 \mathrm{~S} / 23 \mathrm{~S}$ intergenic spacer and Domain I of the $23 \mathrm{~S}$ gene. Primer 170 matches the $16 \mathrm{~S}$ ribosomal gene sequence in all known chlamydiae ( $>50$ strains) and a chlamydia-like organism, beginning 45 bases from the $3^{\prime}$ end of the $16 \mathrm{~S}$ ribosomal gene. Primer 23R complements the 23S ribosomal gene sequence in $>50$ strains of chlamydiae, terminating 211 bases into the $23 \mathrm{~S}$ ribosomal gene. The ribosomal PCR products were amplified with a PCR reagent kit (Perkin Elmer, Foster City, CA) using a thermal cycler (Hybaid OmniGene Temperature Cycler, Middlesex, UK) with the following parameters: 35 cycles of 25 seconds at $95 \mathrm{C}, 15$ seconds at 50 $\mathrm{C}$, and 40 seconds at $72 \mathrm{C}$ and one final extension cycle of 7 minutes at $72 \mathrm{C}$. PCR amplification of $1.1 \mathrm{~kb}$ of the chlamydial ompl gene was done using primers CTU (5'-ATGAAAAAACTCTTGAAATCGG-3') and CTL (5'-CAAGATTTTCTAGA(T/C)TTCAT(C/T)TTGTT- $\left.3^{\prime}\right)^{5}$ as described above, but the annealing conditions were $51 \mathrm{C}$ for 1 minute and extension time was 1 minute. The omp 1 products encode $80 \%$ of a gene that expresses the chlamydial major outer protein.

The PCR products were extracted with phenol/chloroform and with chloroform and concentrated over microconcentrators (Microcon 100, Amicon, Beverly, MA). Several volumes of water were used to wash out the primers and to dilute them to the following concentrations: R33 ribosomal, $1.5 \mu \mathrm{g}$ in $27 \mu \mathrm{l}$; R33 omp1, $3.8 \mu \mathrm{g}$ in $34 \mu \mathrm{l}$; R27 ribosomal, $1.5 \mu \mathrm{g}$ in $27 \mu \mathrm{l}$; R27 ompl, $2.6 \mu \mathrm{g}$ in $30 \mu \mathrm{l}$. Purified PCR product was labeled by random priming with digoxigenindUTP using a commercial kit (Boehringer Mannheim, Indianapolis, IN) following the manufacturer's instructions.

\section{In situ hybridization}

Paraffin-embedded sections were cut at $4 \mu \mathrm{m}$, placed on Superfrost/plus slides (Fisher Scientific, Pittsburgh, PA), and stored at room temperature for in situ hybridization. Tissue sections were deparaffinized and rehydrated in PBS (pH 7.4, $0.01 \mathrm{M}$ ) for 5 minutes just prior to use. Deproteinization was done in $0.2 \mathrm{~N} \mathrm{HCl}$ for 20 minutes at room temperature. Tissue sections were then digested at $37 \mathrm{C}$ for 20 minutes in $20 \mu \mathrm{g} / \mathrm{ml}$ proteinase $\mathrm{K}$ (Gibco BRL, Grand Island, NY) in PBS (pH 7.4, $0.01 \mathrm{M}$ ) and fixed in 4\% paraformaldehyde in PBS for 5 minutes. After rinsing twice in PBS, the slides tissue sections were acetylated in $30 \mathrm{ml}$ of $0.1 \mathrm{mM}$ triethanolamine $\mathrm{HCl}$ buffer ( $\mathrm{pH} 8.0$ ) to which $0.75 \mathrm{ml}$ of acetic anhydride $(0.25 \%)$ was added. After 5 minutes, $0.75 \mathrm{ml}$ of acetic anhydride was added for an additional 5 minutes, and the tissue sections were then rinsed in $2 \times$ standard sodium citrate (SSC; $1 \times \mathrm{SSC}$ is $50 \mathrm{mM} \mathrm{NaCl}$ and $15 \mathrm{mM}$ sodium citrate, $\mathrm{pH} 7.0)$.

The tissue sections were allowed to equilibrate for $60 \mathrm{~min}-$ utes in standard hybridization buffer that consisted of $5 \times$ SSC, 50\% deionized formamide, 2\% $10 \times$ blocking buffered solution (Boehringer Mannheim), 0.1\% N-lauroylsarcosine, and $0.02 \%$ sodium dodecyl sulfate. Hybridization was carried out overnight at $45 \mathrm{C}$. The digoxigenin-labeled probe $(0.1 \mathrm{ng} / \mu \mathrm{l})$ was diluted in $300 \mu \mathrm{l}$ of the standard hybridization buffer, heated for 5 minutes in a $95 \mathrm{C}$ heating block, and then quenched on ice before application to the tissue sections. Approximately $75 \mathrm{ng}$ of the digoxigenin-labeled probes was put into $70 \mu \mathrm{l}$ of the standard hybridization solution buffer and layered over the tissue sections. The fluid was held in place by a coverslip, and the edges were sealed with rubber cement. After overnight hybridization, tissue sections were subjected to two stringent 5-minute washes in $4 \times \mathrm{SSC}$ at room temperature followed by one wash in $2 \times$ SSC for 10 minutes at $37 \mathrm{C}$. Tissue sections were then washed once in $0.2 \times \mathrm{SSC}$ containing $60 \%$ formamide for 10 minutes at $37 \mathrm{C}$, twice in $2 \times \mathrm{SSC}$ for 5 minutes at room temperature, twice in $0.2 \times \mathrm{SSC}$ for 5 minutes at room temperature, and once in buffer I (100 mM maleic acid, 150 $\mathrm{mM} \mathrm{NaCl})(\mathrm{pH} 7.5)$ for 5 minutes at room temperature.

Tissue sections were incubated with antidigoxigenin conjugated with alkaline phosphatase (Boehringer Mannheim) diluted $1: 200$ in $0.1 \mathrm{M}$ Tris- $\mathrm{HCl}(\mathrm{pH} \mathrm{7.4)}$ and $0.15 \mathrm{M} \mathrm{NaCl}$ with 1\% blocking reagent (Boehringer Mannheim) for the detection of hybrids. After three washes in buffer I, substrate consisting of nitroblue tetrazolium (NBT) and 5-bromocresyl-3-indolylphosphate (BCIP) was layered over the sections. Color was allowed to develop for 5-8 hours in the dark, and the reaction was stopped by dipping the slides briefly in Tri-EDTA (10 mM Tris-HCl, $1 \mathrm{mM}$ EDTA) buffer ( $\mathrm{pH}$ 8.0). Tissue sections were counterstained with $0.5 \%$ methyl green, washed with distilled water for 1 minute, and then allowed to dry completely.

\section{Results}

Chlamydia trachomatis strain R33 was detected in the lungs of all intralaryngeally inoculated pigs with the probe made using the R33 strain. There was no difference in intensity of hybridization signals between rRNA and ompl mRNA probes to detect $C$. trachomatis strain R33 in lung tissues. The morphology of host cells was preserved despite the relatively high temperature required in parts of the incubation procedure. Positive cells typically were dark brown to black, and there was no background staining. Generally, individ- 




Fig. 1. Lung; piglet necropsied 7 days postinoculation. Chlamydial nucleic acid (dark brown reaction) appears in scattered bronchiolar epithelium. In situ hybridization; rRNA probe, NBT/BCIP, methylgreen counterstain. Bar $=55 \mu \mathrm{m}$.

Fig. 2. Lung; piglet necropsied 7 days postinoculation. Chlamydial nucleic acid (dark brown reaction) appears in scattered thickened alveolar septa. In situ hybridization; opm 1 mRNA probe, NBT/BCIP, methylgreen counterstain. Bar $=55 \mu \mathrm{m}$. ual positive cells were scattered; however, occasionally there was a focus in which several positive cells were aggregated. Bronchial and bronchiolar epithelial cells (Fig. 1), pneumocytes, and alveolar macrophages all had positive hybridization signals. An especially strong hybridization signal was detected in interstitial and alveolar macrophages in the thickened alveolar septa and spaces (Fig. 2).

Chlamydia trachomatis strain R27 was detected in the jejunum and ileum of all orally inoculated pigs with the probe made using the R27 strain. There was no difference in intensity of hybridization signals between rRNA and ompl mRNA probes to detect $C$. trachomatis strain R27 in intestinal tissues. There were strong hybridization signals in the cytoplasm of enterocytes lining the apical portions of villi, typically in areas of vacuolated enterocytes and moderate to severe villus atrophy (Fig. 3). There was no hybridization signal in epithelial cells lining the crypts of Lieberkühn. There were no hybridization signals in the lung and intestinal tissues from the control pigs or in the sheep placenta infected with C. psittaci.

\section{Discussion}

This is the first demonstration of swine chlamydial nucleic acid by in situ hybridization in formalin-fixed, paraffin-embedded tissue specimens using a nonradioactive labeled DNA probe. C. trachomatis antigen has been detected in bronchial and bronchiolar epithelial cells, pneumocytes, alveolar and interstitial macrophages, and jejunal and ileal villus enterocytes of swine using polyclonal-antibody-based immunohistochemical procedures. ${ }^{20,22,34}$ However, use of DNA probes and in situ hybridization eliminates possibilities for error caused by antigenic cross-reactivity or by the alteration of binding sites during tissue processing. Formalin fixation can denature antigens, which can lead to false-negative results. ${ }^{10,19}$ In contrast to immunohistochemistry, in situ hybridization is less susceptible to structural alteration caused by fixation. ${ }^{9}$

The R33 and R27 swine ribosomal probe sequences differ from the ribosomal sequences of other swine strains by $0.4-3 \%$, and they differ from human and mouse strains of $C$. trachomatis by 3-5\%. These ribosomal probes differ from all strains of $C$. psittaci, $C$. pneumoniae, and $C$. pecorum by $15-18 \%$. They also differ from the most closely related chlamydia-

$\leftarrow$

Fig. 3. Jejunum; piglet necropsied 4 days postinoculation. Chlamydial nucleic acid (dark brown reaction) is present in epithelium covering moderately atrophic villi. In situ hybridization; rRNA probe, NBT/BCIP, methylgreen counterstain. Bar $=80 \mu \mathrm{m}$. 
like sequence by $50 \%$, with most of the conservation located in the $16 \mathrm{~S}$ and $23 \mathrm{~S}$ portions of the PCR product. The R33 and R27 omp1 probes differ $24 \%$ from each other, and they differ $16-24 \%$ from other swine strains. The swine omp 1 probes differ $26-31 \%$ from human and mouse $C$. trachomatis strains, and they differ $42-52 \%$ from all other strains of Chlamydia (unpublished data). Thus, a complementary DNA probe from swine $C$. trachomatis could be used for the specific detection of $C$. trachomatis in swine tissue specimens.

Currently, the diagnosis of chlamydial infection is based primarily upon the isolation of the organism in either HeLa or McCoy cells. However, the sensitivity of such isolations are typically $90-95 \%$ compared with that of other methods..$^{15}$ Direct fluorescent antibody tests and enzyme immunoassays using monoclonal antibodies have been described and compared with culture methods for the detection and identification of $C$. trachomatis. ${ }^{25}$ However, none of the immunoassays have been highly sensitive or specific. ${ }^{25}$ PCR procedures $^{30}$ and molecular hybridization screening systems that target chlamydial nucleic acids ${ }^{4}$ can detect those molecules with high specificity and sensitivity, but they can give no information regarding the specific location of $C$. trachomatis in tissues. In situ hybridization can be useful in addressing all these questions; it can be used to identify the types of infected host cells with high specificity and sensitivity.

Probes used in previous in situ hybridization assays targeting $C$. trachomatis have consisted of the chlamydial plasmid, cloned fragments of the chlamydial chromosome, or total chlamydial chromosomal DNA. Various methods of probe labeling, including radioactivity and biotinylation, have been used in to investigate human chlamydial infections. ${ }^{3,6,11,12,16}$ However, all of these methods are inadequate for the examination of clinical samples. ${ }^{2}$ Furthermore, chlamydiae lacking a specific plasmid have been described, ${ }^{1}$ and the use of such DNA sequences as probes would be problematic.

This new in situ hybridization system is highly specific and employs a nonradioactively labeled DNA probe that is targeted to specific chlamydial rRNA sequences. This system can be used with formalin-fixed, paraffin-embedded tissue specimens and can distinguish C. trachomatis from C. psittaci infection.

\section{Acknowledgement}

This research was supported by contract funds of the Research Institute for Veterinary Science (RIVS), College of Veterinary Medicine, Seoul National University, Republic of Korea.

\section{References}

1 An Q, Radcliffe G, Vassallo R, Buxton D, O'Brien WJ, Pelletier DA, Weinsburg WG, Klinger JD, Olive DM: Infection with a plasmid-free variant chlamydia related to Chlamydia trachomatis identified by using multiple assays for nucleic acid detection. J Clin Microbiol 30: 2814-2821, 1992

2 Beutler AM, Schumacher HR, Whittum-Hudson JA, Salameh WA, Hudson AP: Case report: in situ hybridization for detection of inapparent infection with Chlamydia trachomatis in synovial tissue of a patient with Reiter's syndrome. Am J Med Sci 310:206-213, 1995

3 Campbell LA, Patton DL, Moore DE, Cappuccio AL, Mueller BA, Wang SP: Detection of Chlamydia trachomatis deoxyribonucleic acid in women with tubal infertility. Fertil Steril 59:45-50, 1993

4 Cheema MA, Schunacher HR, Hudson AP: RNA-directed molecular hybridization screening: evidence for inapparent chlamydial infection. Am J Med Sci 302:261268, 1991

5 Denamur E, Sayada C, Sourian J, Orfila J, Rodolakis A, Elion J: Restriction pattern of the major outer-membrane protein gene provides evidence for a homogeneous invasive group among ruminant isolates of Chlamydia psittaci. J Gen Microbiol 137:2525-2530, 1991

6 Dutilh B, Bebear C, Taylor-Robinson D, Grimont PAD: Detection of Chlamydia trachomatis by in situ hybridization with sulphonated total DNA. Ann Inst Pasteur Microbiol 139:115-128, 1988

7 Everett KDE, Andersen AA: Classification of chlamydiae by rDNA sequence analysis. Proc Eur Soc Chlamydia Res 3:28, 1996

8 Everett KDE, Andersen AA: The ribosomal intergenic spacer and domain I of the 23S rRNA gene are phylogenetic markers for Chlamydia spp. Int J Syst Bacteriol 47:461-473, 1997

9 Greogory CR, Latimer KS, Niagro FD, Campagnoli RP, Steffens WL, Ritchie BW: Detection of eastern equine encephalomyelitis virus RNA in formalin-fixed, paraffinembedded tissues using DNA in situ hybridization. J Vet Diagn Invest 8:151-155, 1996

10 Haines DM, Chelack BJ: Technical considerations for developing enzyme immunohistochemical staining procedures on formalin-fixed paraffin-embedded tissues for diagnostic pathology. J Vet Diagn Invest 3:101-112, 1991

11 Horn JE, Hammer ML, Falkow S, Quinn TC: Detection of Chlamydia trachomatis in tissue culture and cervical scraping by in situ hybridization. J Infect Dis 153:11551159, 1986

12 Horn JE, Kappus EW, Falkow S, Quinn TC: Diagnosis of Chlamydia trachomatis in biopsied tissue specimens using in situ DNA hybridization. J Infect Dis 157:12491253, 1988

13 Kaltenboeck B, Storz J: Biological properties and genetic analysis of the omp $A$ locus in chlamydiae isolated from swine. Am J Vet Res 53:1482-1487, 1992

14 Kobl O, Burtscher H, Hebenstreit J: Polyarthritis in slaughter swine with reference to microbiological and 
histological findings and aspects of meat hygiene. Wien Tierärztl Monatsschr 57:355-361, 1970

15 LeBar W, Herschman B, Jemal C, Pierzchala J: Comparison of a DNA probe, monoclonal antibody enzyme immunoassay, and cell culture for the detection of Chlamydia trachomatis. J Clin Microbiol 27:826-828, 1989

16 Naher H, Petzoldt D, Sethi KK: Evaluation of non-radioactive in situ hybridization method to detect Chlamydia trachomatis in cell culture. Genitourin Med 64: 162-164, 1988

17 Nietfeld JC, Janke BH, Leslie-Steen P, Robinson DJ, Zeman DH: Small intestinal Chlamydia infection in piglets. J Vet Diagn Invest 5:114-117, 1993

18 Pospischil A, Wood RL: Intestinal Chlamydia in pigs. Vet Pathol 24:568-570, 1987

19 Rickert RR, Maliniak RM: Intralaboratory quality assurance of immunohistochemical procedures. Arch Pathol Lab Med 113:673-679, 1989

20 Rogers DG, Andersen AA: Intestinal lesions caused by two swine chlamydial isolates in gnotobiotic pigs. J Vet Diagn Invest 8:433-440, 1996

21 Rogers DG, Andersen AA, Hogg A, Nielsen DL, Huebert MA: Conjunctivitis and keratoconjunctivitis associated with chlamydiae in swine. J Am Vet Med Assoc 203:1321-1323, 1993

22 Rogers DG, Andersen AA, Hunsaker BD: Lung and nasal lesions caused by a swine chlamydial isolate in gnotobiotic pigs. J Vet Diagn Invest 8:45-55, 1996

23 Sambrook J, Fritsch EF, Maniatis T: Molecular Cloning: A Laboratory Manual. Cold Spring Harbor Laboratory Press, Cold Spring Harbor, NY, 1989

24 Sarma DK, Tamuli MK, Rahman T, Boro BR, Deka BC, Rajkonwar CK: Isolation of chlamydia from a pig with lesions in the urethra and prostate gland. Vet Rec 112: 525,1983
25 Stamm WE: Diagnosis of Chlamydia trachomatis genitourinary infections. Ann Intern Med 108:710-717, 1988

26 Stellmacher H, Kielstein P, Horsch F, Martin J: Zur bedeutung der chlamydieninfektion des schweines unter besonder berucksichtigung der pneumonien. Monatsch Veterinärmed 38:601-606, 1983

27 Storz J, Kaltenboeck B: The Chlamydiales. In: Rickettsial and Chlamydial Diseases of Domestic Animals, ed. Woldehiwet Z and Ristic M, pp. 27-64. Pergamon Press, Oxford, UK, 1993

28 Szeredi L, Schiller I, Sydler T, Guscetti F, Heinen E, Corboz L, Eggenberger E, Jones GE, Pospischil A: Intestinal Chlamydia in finishing pigs. Vet Pathol 33:369374, 1996

29 Thoma R, Guscetti F, Schiller I, Schmeer N, Corboz L, Pospischil A: Chlamydiae in porcine abortion. Vet Pathol 34:467-469, 1997

30 Welch D, Lee CH, Larsen SH: Detection of plasmid DNA from all Chlamydia trachomatis serovars with a two-step polymerase chain reaction. Appl Environ Microbiol 56:2494-2498, 1990

31 Willigan DA, Beamer PD: Isolation of a transmissible agent from pericarditis of swine. J Am Vet Med Assoc 126:118-122, 1955

32 Wittenbrink MM, Wen X, Böhmer N, Amsberg G, Binder A: Bacteriological investigations into the incidence of Chlamydia psittaci in organs from swine and in aborted porcine fetuses. J Vet Med B 38:411-420, 1991

33 Woolen N, Daniels EK, Yeary T, Leipold HW, Philips RM: Chlamydial infection and perinatal mortality in a swine herd. J Am Vet Med Assoc 197:600-601, 1990

34 Zahn I, Szeredi L, Schiller I, Straumann Kunz U, Bürgi E, Guscetti F, Heinen E, Corboz L, Sydler T, Pospischil A: Immunohistologischer nachweis von Chlamydia psittaci/pecorum und C. trachomatis im Ferkel-Darm. J Vet Med B 42:266-276, 1995

Request reprints from Dr. C. Chae, Department of Veterinary Pathology, College of Veterinary Medicine, Seoul National University, Suwon, Kyounggi-Do 441-744 (Republic of Korea). E-mail: swine@plaza.snu.ac.kr. 